\title{
Review
}

\section{Kropotkin: Reviewing the classical Anarchist tradition}

\author{
Ruth Kinna \\ Edinburgh University Press, 2016, v + 266pp., \\ ISBN 978-1474428378 (2017 Paperback Edition)
}

Contemporary Political Theory (2019) 18, S183-S186. https://doi.org/10.1057/s41296018-0205-8; published online 15 March 2018

The Russian geographer, philosopher and prince-turned-revolutionary Peter Kropotkin (1842-1921) is beyond doubt one of the most significant theorists in the anarchist tradition - and, more generally, in the history of radical political thought. But, as is often the case with important political theorists, Kropotkin's work is read in many different ways and has been employed to serve various political agendas. Several over-idealised and negative stereotypes have been created in the course of the past century. The aim of Ruth Kinna's thoroughly researched and tightly argued study is to 'rescue Kropotkin' (p. 1) and to debunk some of the most prevalent misconceptions that surround his life and work. This should allow us not only to appreciate the creativity and radicality of this original thinker, but also to re-assess some of his political choices - including his controversial support for the Entente powers during WWI.

What exactly is Kinna trying to 'rescue' Kropotkin from? In Part One of her book she offers a dense overview of the various ways in which anarchist theorists have sought to canonise his work. First, we encounter the popular image of Kropotkin as a compassionate and mildly tempered 'old man,' who was the first to establish anarchism as a scientific theory. This representation - which is often counterpoised to that of Mikhail Bakunin as a bohemian and passionate propagator of revolutionary violence (Woodcock, 1963, pp. 171-172) - has given rise to the misconception that Kropotkin merely advocated 'ethical and cultural change as a route to structural transformation' (p. 22). Kinna rightly stresses that this benign image of 'saint Kropotkin' obscures the significant role and meaning of revolutionary struggle in his political thought.

New interpretations of Kropotkin have emerged in the recent contemporary anarchist debate. On the one hand, his work is inscribed in a particular reading of anarchism as a distinctive working-class tendency, which excludes prominent individualists such as Max Stirner (Schmidt and Van der Walt, 2009, pp. 44-47). 'Post-anarchist' theorists, on the other hand, criticise Kropotkin for his supposed endorsement of Enlightenment values and his essentialist concept of human nature.

(c) 2018 Macmillan Publishers Ltd., part of Springer Nature. 1470-8914 Contemporary Political Theory Vol. 18, S3, S183-S186 www.palgrave.com/journals 
They present Kropotkin as a key exponent of the 'classical' anarchist tradition, which then is contrasted with an individualist and ontologically anarchic tendency, harking back precisely to Stirner as a post-anarchist avant la lettre (Newman, 2001, pp. 41-42). Kinna criticises how these various readings of Kropotkin's work tend to position him on one side of a conceptual distinction between opposite strands of anarchist thought. In all these cases, Kropotkin's legacy is easily 'soaked up' in a general narrative that fails to do justice to his originality and creativity. As the book's subtitle suggests, however, Kinna points her critical arrows at the postanarchists in particular. Their invention of a 'classical' anarchist tradition 'is not only an obstacle to the study of Kropotkin's ideas; it is a distorting lens for movement histories' (p. 46).

In the remaining two parts of her book, Kinna presents a careful rereading of Kropotkin as an original radical theorist. Her thoughtful analysis has two great merits. First, it discusses Kropotkin's best-known works, such as The Conquest of Bread (1892) or Mutual Aid (1902), as well as his lesser-known writings on ethics and the history of Russian literature. Second, although it roughly follows the chronology of Kropotkin's life, Kinna's account never becomes anecdotal or overly biographic - as often tends to be the case in monographs on prominent revolutionaries. She instead situates Kropotkin in the rich and dynamic intellectual landscape in which his ideas came to fruition. This allows Kinna to show his oeuvre in a different light.

Part Two reconstructs how Kropotkin's Russian background informed his endorsement of anarchist ideas. For those who hold a stereotypical view of Russian nihilism (a view often based on Nietzsche's use of the term), it may come as a surprise that the theorist of mutual aid was strongly influenced by this tradition. Far from a philosophy of despair, as it is often perceived, Kropotkin took nihilism to be the foundation of an anarchist ethics and a politics of hope. He held that the novels of Turgenev and Chernyshevsky promoted an attitude of 'thoughtful realism,' and that they encouraged the Russian youth to question the religious superstition and authority of their parents' generation. Moreover, the nihilists also made a significant contribution to the emancipation of women in Russia. Kinna explains how Kropotkin's experiences with Tsarism and his geographic studies of the Russian landscape have shaped his understanding of the state and his critique of representative government. Kropotkin realised that states will always serve to protect the rich and powerful against the poor and weak, and that they continuously seek to expand their domination over a territory. This is what renders his analysis typically anarchist: the state is not reduced to a purely economic function, but is also a source of oppression in its own right. For revolutionary politics, any form of engagement with the state is thus futile. Instead, the answer lies in organisation through federation from below, and in the establishment of international networks of solidarity.

S184 (c) 2018 Macmillan Publishers Ltd., part of Springer Nature. 1470-8914 Contemporary Political Theory Vol. 18, S3, S183-S186 
At first sight, this may also explain why Kropotkin's support for the Entente powers surprised and infuriated so many of his radical contemporaries. Arguably the most interesting aspect of Part Three is Kinna's nuanced explanation of this controversial choice - which was not quite as inconsistent as some of Kropotkin's comrades claimed. He was well aware that this war resulted from the very same statism and capitalism that he so despised. However, at the same time, Germany most eminently embodied the very colonialism and domination that characterise centralised states. Even the German Social Democratic Party had conceded to this logic by endorsing an electoral strategy, seeking state power for itself. Kropotkin hoped that what he perceived to be the war's main aggressor would be forced to a halt.

Does Kinna accomplish her mission to 'rescue Kropotkin' from the many misconceptions that exist around his life and work - and from his image as a 'classical' anarchist? Although he clearly stands in the long tradition of anarchism, this book indeed urges us to approach Kropotkin as an independent and creative thinker. The influence of Russian nihilism, the complex relation between utopianism and science, his original concept of the state, and many other aspects of his oeuvre suggest that Kropotkin's legacy cannot simply be reduced to that of a positivist scientist.

The only remaining question, then, is: why would we want to save Kropotkin from this (admittedly very limited) representation? What exactly is at stake here? Kinna stresses from the outset that her interest in Kropotkin is mostly academic: ' $[t]$ he point of hovering over Kropotkin's work for a while is not to elicit lessons for twenty-first century action' (p. 2). Such self-constraint is legitimate, but it is also somewhat disappointing - especially because the post-anarchist narrative that Kinna seeks to counter here is no less academic in tone and orientation, and arguably has had very little impact on activist practice. The risk, in other words, is that we end up in a purely theoretical debate, and thus lose sight of the kind of questions that made Kropotkin such an important radical figure. What may a new generation of activists be able to learn from him about revolutionary politics and radical change today? How can Kropotkin's concept of the state or his ethical framework be employed in a contemporary radical debate? Addressing such questions may have done very little to increase the academic rigour and significance of this impressive study, but it could have made it more relevant and accessible for a wider audience.

\section{References}

Newman, S. (2001) From Bakunin to Lacan: Anti-Authoritarianism and the Dislocation of Power. Plymouth: Lexington Books.

() 2018 Macmillan Publishers Ltd., part of Springer Nature. 1470-8914 Contemporary Political Theory Vol. 18, S3, S183-S186 S185 
Schmidt, M. and van der Walt, L. (2009) Black Flame: The Revolutionary Class Politics of Anarchism and Syndicalism. Oakland and Edinburgh: AK Press.

Woodcock, G. (1963) Anarchism: A History of Libertarian Ideas and Movements. Harmondsworth: Penguin Books.

Mathijs van de Sande

Radboud University Nijmegen, 6525 HP Nijmegen, The Netherlands m.vandesande@ftr.ru.nl 